\title{
Effect of Gender on Morphohistopathological Changes of Basilar Arteries Following Bilateral Common Carotid Artery Ligation: An Experimental Study
}

\section{Bilateral Arteria Carotis Communis Ligasyonu Sonrası Arteria Basilaris'te Gözüken Morfohistopatolojik Değişikliklere Cinsiyetin Etkisi: Deneysel Çalışma}

\author{
@Cengiz Öztürk', @Kemal Alp Nalcı², @Onur Ceylan³, @ismail Malkoç4, @Mehmet Dumlu Aydın \\ 'Atatürk University, Faculty of Medicine, Department of Anatomy, Erzurum, Turkey \\ ${ }^{2}$ Atatürk University, Faculty of Medicine, Medical Pharmacology, Erzurum, Turkey \\ ${ }^{3}$ Atatürk University, Faculty of Medicine, Medical Pathology, Erzurum, Turkey \\ ${ }^{4}$ Düzce University, Faculty of Medicine, Department of Anatomy, Düzce, Turkey \\ ${ }^{5}$ Atatürk University, Faculty of Medicine, Department of Brain and Nerve Surgery, Erzurum, Turkey
}

Copyright @ 2020 by authors and Medical Records Publishing Inc.

\begin{abstract}
Aim: Steno-occlusive carotid artery disease causes increased pressure, retrograde blood flow, luminal enlargement, vascular wall thinning, elongation, convolutions, vascular re-modelization, and aneurysm formation in basilar arteries. We investigated if gender affects the severity of histomorphologic alterations of basilar arteries after bilateral common carotid artery ligation.

Material and Methods: This study was conducted on 7 male and 7 female rabbits. Two of both male and female rabbits were used as a control group and the remaining were used as the study group. Permanent ligation of the common carotid arteries from just proximal of bifurcation was performed to replicate steno-occlusive carotid artery disease. Basilar artery volumes were measured by stereological methods after the sacrifice of the animals at the end of the 3rd week. Results were compared Mann-Witney U test between groups.

Results: Luminal enlargement, wall thinning, elongation, convolutions, and doligoectatic configurations were detected in the majority of basilar arteries. The mean basilar arterial volume values were estimated as male rabbits were $3.65 \pm 0.35 \mathrm{~mm} 3$ in control and $4.96 \pm 0.99$ $\mathrm{mm} 3$ in the study group. The mean basilar arterial volume values were estimated as female rabbits were $3.97 \pm 0.40 \mathrm{~mm} 3$ in control and $6.32 \pm 1.13 \mathrm{~mm} 3$ in the study group. The severity of basilar enlargement was significantly higher in the female rabbits compared with the male rabbits $(p<0.01)$.

Conclusion: Bilateral common carotid artery ligation causes more severe luminal enlargement, wall thinning, elongation, convolution, and aneurysm formation in female rabbits than males.
\end{abstract}

Keywords: Bilateral common carotid artery ligation (BCCAL), basilar artery (BA), stereological method

$\mathrm{Oz}$

Amaç: Steno-oklüziv karotis arter hastalığı baziler arterde yüksek kan basıncı, retrograd kan akımı, lüminal genişleme, vasküler duvar incelmesi, uzama, kıvrılma, vasküler remodelizasyon ve anevrizmalara sebep olabilir. Biz cinsiyetin bilateral arteria carotis communis ligasyonu sonucu oluşan histomorfolojik değişikliklerin derecesine olan etkisini araştırdık.

Materyal ve Metot: Bu çalışma 7 dişi ve 7 erkek tavşan üzerinde yapılmıştır. Hem erkek hem de dişi tavşanlardan ikisi kontrol, diğerleriyse deney grubu olarak kullanıldı. Arteria carotis communis bifurkasyonunun hemen proksimalinden uygulanan kalıcı ligasyon, steno-oklüziv karotis arter hastalığını tekrarlamak için yapıldı. Hayvanlar üzerinde yapılan bu çalışmanın 3. haftasında baziler arter hacmi stereolojik yöntemlerle ölçüldü. Sonuçlar Mann-Whitney U testi ile karşılaştırıldı.

Bulgular. Baziler arterlerde büyük oranda lüminal genişleme, duvar değişiklikleri (uzama, incelme, kıvrılma) ve dolikoektazik (uzama ve genişleme) değişiklikler tespit edildi. Baziler arterlerin ortalama hacmi erkek kontrol grubu tavşanlarında 3,65 $\pm 0,35 \mathrm{~mm} 3$, erkek deney tavşanlarında ise $4.96 \pm 0.99 \mathrm{~mm} 3$ olarak değerlendirildi. Baziler arterlerin ortalama hacim değerleri dişi kontrol grubu tavşanlarında $3,97 \pm 0,40 \mathrm{~mm} 3$, dişi deney tavşanlarında ise $6,32 \pm 1,13 \mathrm{~mm} 3$ olduğu tespit edildi. Baziler arter genişlemesi dişi tavşanlarda erkeklerden gözle görülür derecede belirgindi $(p<0.01)$.

Sonuç: Bilateral arteria carotis communis ligasyonu, dişi tavşanlarda erkek tavşanlara göre daha belirgin luminal genişleme, duvar incelmesi, uzama, kıvrılma ve anevrizmalara sebep oluyor.

Anahtar Kelimeler. Bilateral arteria carotis communis ligasyonu, baziler arterler, stereolojik yöntem 


\section{INTRODUCTION}

Bilateral common carotid artery ligation (BCCAL) resulted a major redistribution of blood to the head, with increased flow through the vertebral and basilar arteries. A rat model was developed to examine bilateral common carotid artery (BCCA) changes in the posterior circle of Willis and the basilar and intracranial vertebral arteries after BCCAL. Changes in the vertebral, basilar, posterior communicating, and proximal segments of the posterior cerebral arteries and neck vessels were assessed by postmortem barium sulfate arteriography and by histology of the middle portion of the basilar arteries serially at four days, and one, two, four and 15 weeks post-ligation. The changes noted were basilar and vertebral artery tortuosity, enlargement, and duplication of the vertebrobasilar junction. By 15 weeks, these intracranial vascular changes had largely regressed toward normal, commensurate with the appearance of multiple collateral vessels which were scattered throughout the soft tissues of the neck and shunted the original ligation sites. A mechanism that could explain these trophic vessel changes in response to increased blood flow is discussed. Some possible correlates of these findings with several brain vascular diseases are presented (1). Bilateral common carotid artery occlusion (BCCAO) resulted in the redistribution of blood flow to posteriorly located cerebral arteries with remarkable changes in morphology and perivascular nerve density, suggesting a functional role for perivascular nerves in cerebral autoregulation (2). A meaningful and paradoxical correlation was detected between the BA VDI values and the degenerated neuron density of SCG after BCCAL (3). Bilateral common carotid artery ligation resulting in morphological changes in Circle of Willis morphology of the rat (4). BCCAL may lead to important beneficial and hazardous histomorphological changes at the posterior communicating artery (5). Hemodynamic insult has been speculated to be a key factor in intracranial aneurysm formation following BCCAL (6).

\section{MATERIAL AND METHODS}

This study was conducted on 14 young New Zealand male/female rabbits $(2.50 \pm 0.32 \mathrm{~kg})$ following institutional ethical committee approval. Two of both male and female rabbits were used as a control group and the remaining were used as the study group. A balanced, injectable analgesic (metamizole $30 \mathrm{mg} / \mathrm{kg}$ body weight) was used for reducing pain and mortality. Anesthesia was induced by isoflurane inhalation, followed by $0.2 \mathrm{~mL} /$ $\mathrm{kg}$ of the anesthetic combination (Ketamine HCL,150 $\mathrm{mg} / 1.5 \mathrm{~mL}$; xylazine $\mathrm{HCL}, 30 \mathrm{mg} / 1.5 \mathrm{~mL} ; 1 \mathrm{~mL}$ distilled water combined) injected subcutaneously before surgery. Intraoperatively, $0.1 \mathrm{~mL} / \mathrm{kg}$ was used when required. All animals were laid in the supine position and the anterior cervical regions sterilely prepared. A $3 \mathrm{~cm}$ mid-cervical incision was made and the common carotid artery, vagal nerve, jugular vein, and sympathetic chain were identified bilaterally. The common carotid arteries were dissected and knotted with silk sutures. The animals were observed for 3 weeks postoperatively without medical treatment and then sacrificed. Rabbit brains were stored in $10 \%$ formalin for 7 days, then $5 \mu \mathrm{m}$ tissue sections of the basilar arteries at the mid pontine levels were stained with H\&E and examined histologically. Wall surface/lumen surface ratio was accepted as the vasodilation value estimated from when the wall surface was calculated by subtracting the lumen surface from the total surface.

Consciousness, convulsions, fever, apnea, cardiac arrhythmia, and breathing disturbances were observed frequently in the three surviving animals and in the premortem periods of the animals that died. Anatomicalpathological examination of the brains showed that all basilar arteries were localized to the basilar sulcus and extended from the fusion point of the vertebral arteries to the origin of the posterior cerebral arteries. The average length of the basilar arteries was $18.70 \pm 1.50 \mathrm{~mm}$. On histopathologic examination of the normal basilar arteries, lumen diameter, inner elastic membrane, endothelial cells, vascular wall muscles, and adventitia are shown. Minimal inner elastic membrane flattening, greater luminal surface and basilar artery expansion, wall thinning, and increased basilar artery volume was observed. Basilar artery dilatation was more prominent in female animals. Leptomeningeal thickening, basilar artery elongation, and convolution, doligoectatic configurations were observed macroscopically. In histopathologic examinations of all animals especially female animals was shown inner elastic membrane flattening, intimal thinning, endothelial cell shrinkage, desquamation and loss of endothelial cells, luminal enlargement and dilatation, and wall thinning following BCCAL. Basilar artery duplication, neovascularisation, and/or collateral development in the basilar groove and inferior surface of the pons and paramedian duplicated thin basilar arteries were detected in female animals. We do not use sham group at the same consideration because our aim was to only examined whether gender have any role of basilar artery configuration following BCCAL.

\section{RESULTS}

Histopathological Findings

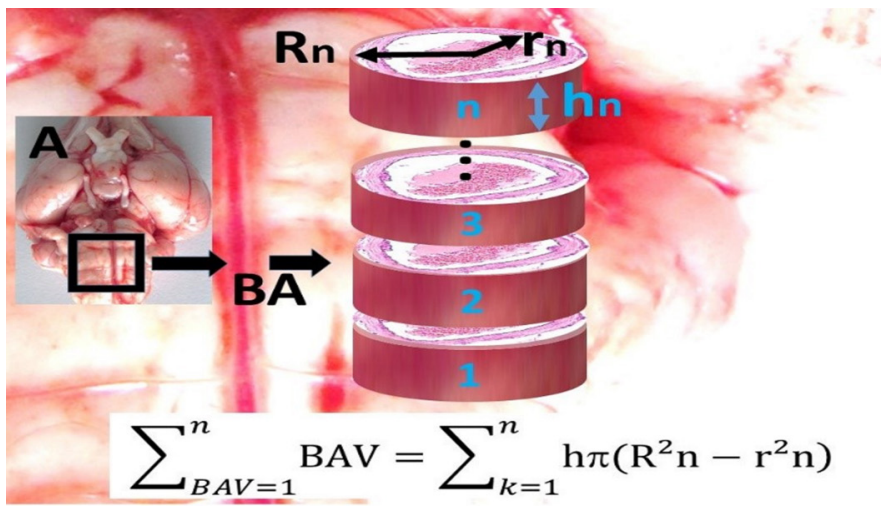

Figure 1. The macroscopic appearance of the brain with the basilar artery (BA) is seen. To estimate total luminal volume values of $B A$, BA were divided to " $n$ " parts and each part volumes calculated by a cylinder volume calculating formula. Then, the sample volume value multiplied with ' $n$ ' and estimated all volume value. We prefer to use lumen volume values to understand the rational dilation velocity of BA following BCCAL. BA has an inner and external diameter. Lumen volume value=External volume value-Wall volume value. BA volume values of all groups were compared and results were analyzed by the Mann-Whitney $U$ test. The formula is seen below the figure 1 


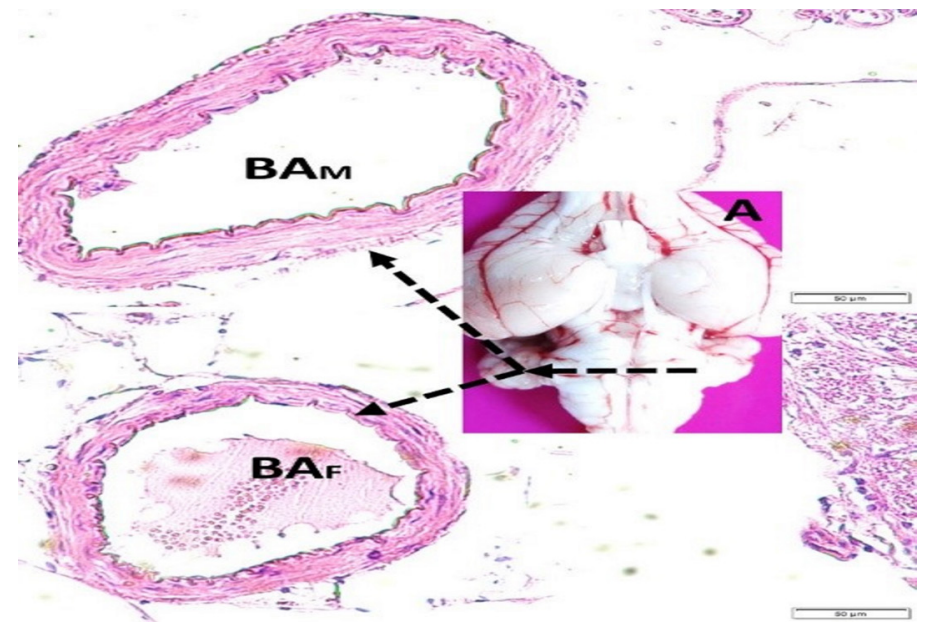

Figure 2. Basal view of a normal brain and localization of basilar artery (BA) and histopathological view of the basilar artery in the basilary sulcus (LM, H\&E, x4/A; x10/B; x20/C)

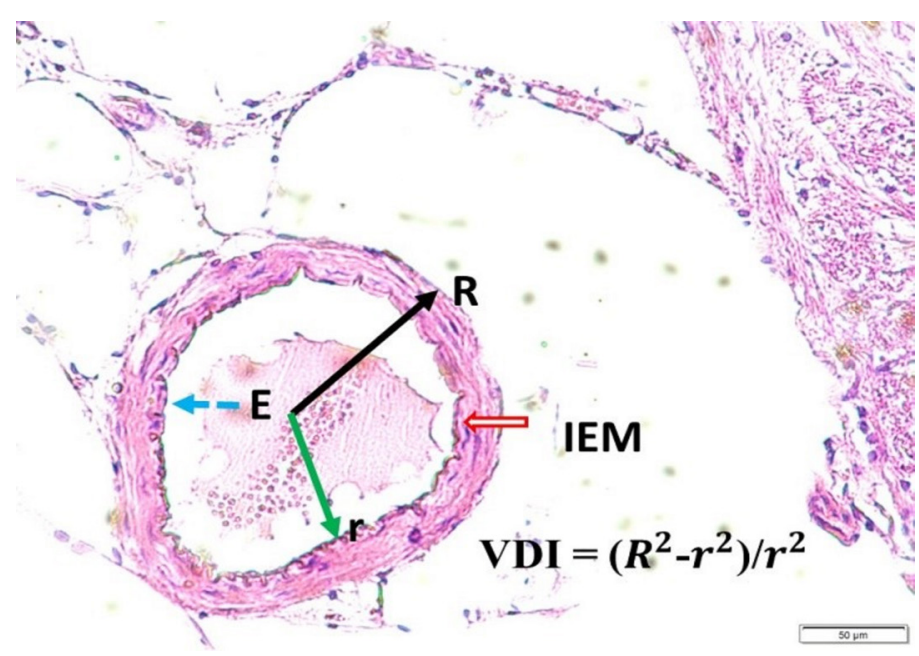

Figure 3. Histologic appearance of the basilar artery in the basilary sulcus in pons with arachnoid membrane/adventitia, inner elastic membrane (IEM), and endothelium (E) of a normal group ( $L M, x 4 / A$; $\mathrm{x} 10 / \mathrm{B} ; \mathrm{x} 20 / \mathrm{C})$

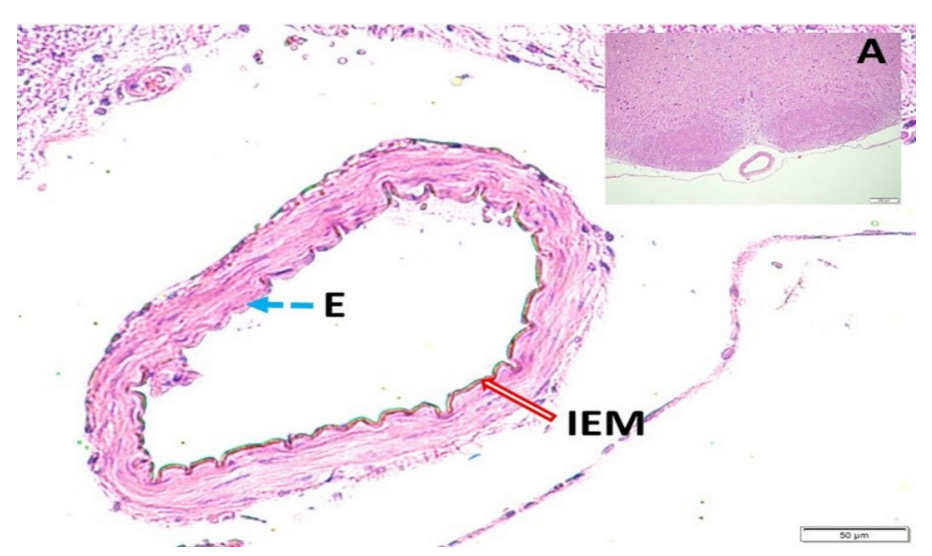

Figure 4. The histopathologic appearance of the basilar artery in basilary sulcus in pons ( $\mathrm{LM}, \mathrm{H} \& \mathrm{E}, 4 / \mathrm{A})$ and magnified form with thickened arachnoid membrane/adventitia, thinned smooth muscles in thinned wall, significant flattened inner elastic membrane (IEM) and endothelium (E) with of male rabbit (LM, H\&E, 20/Base)

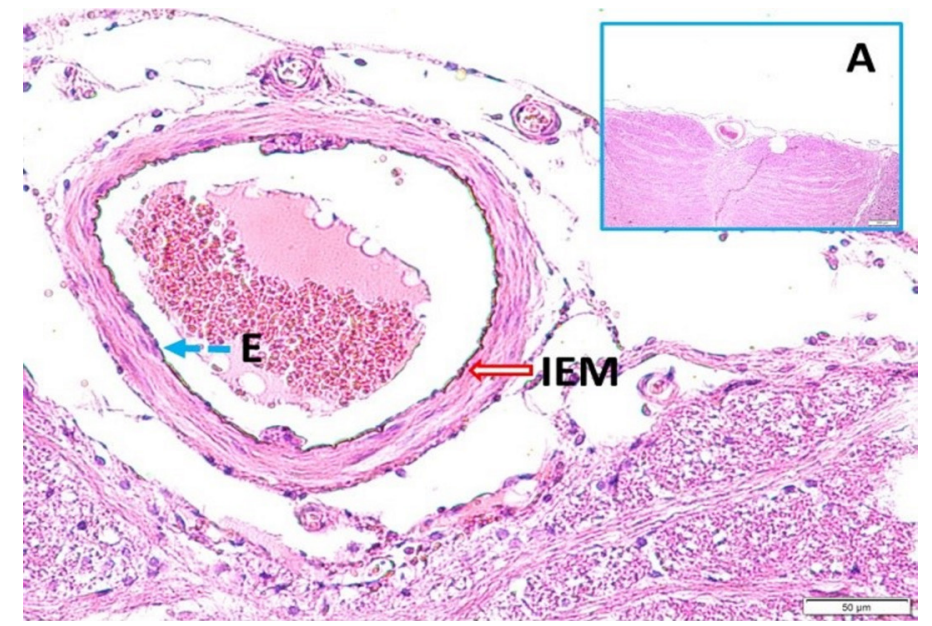

Figure 5. The histopathologic appearance of the basilar artery in basilary sulcus in the pons (LM, H\&E,4/A) and magnified form with thickened arachnoid membrane/adventitia, thinned smooth muscles in a thinned wall, significant flattened inner elastic membrane (IEM) and endothelium of female rabbit (E) with (LM, H\&E, 20/Base)

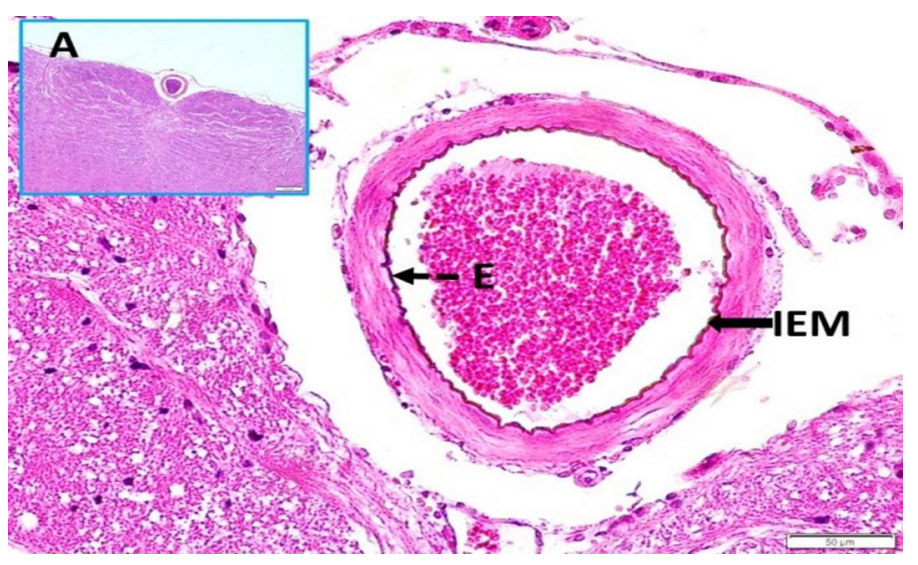

Figure 6. Histopathologic appearance of the basilar artery in the basilar sulcus in pons (LM, H\&E,4/A) and magnified form with thickened arachnoid membrane/adventitia, thinned smooth muscles in thinned wall, significant flattened inner elastic membrane (IEM) and endothelium ( $E$ ) of male rabbit (LM, H\&E, 20/Base).

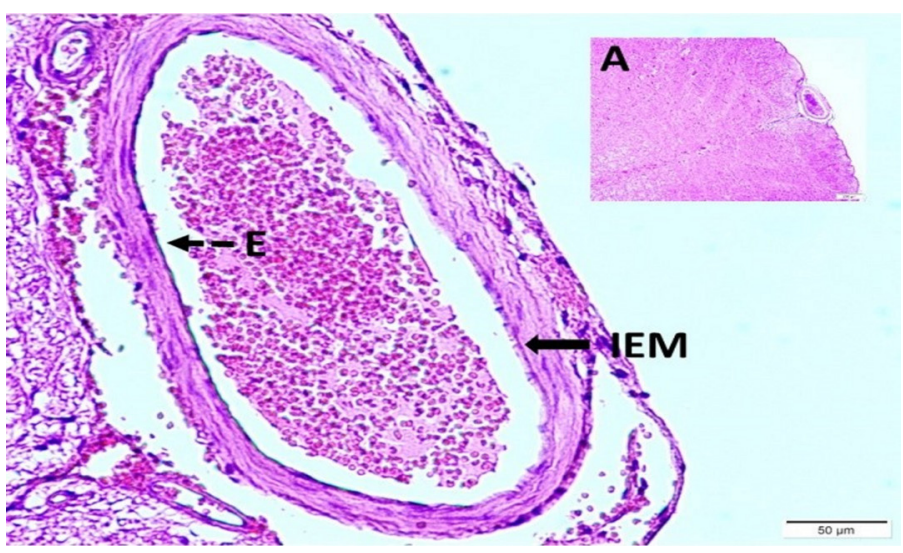

Figure 7. The histopathologic appearance of basilar artery in the basilar sulcus in pons (LM, H\&E,4/A) and magnified form with thickened arachnoid membrane/adventitia, thinned smooth muscles in thinned wall, significant flattened inner elastic membrane (IEM) and endothelium (E) of female rabbit (LM, H\&E, 20/Base) 


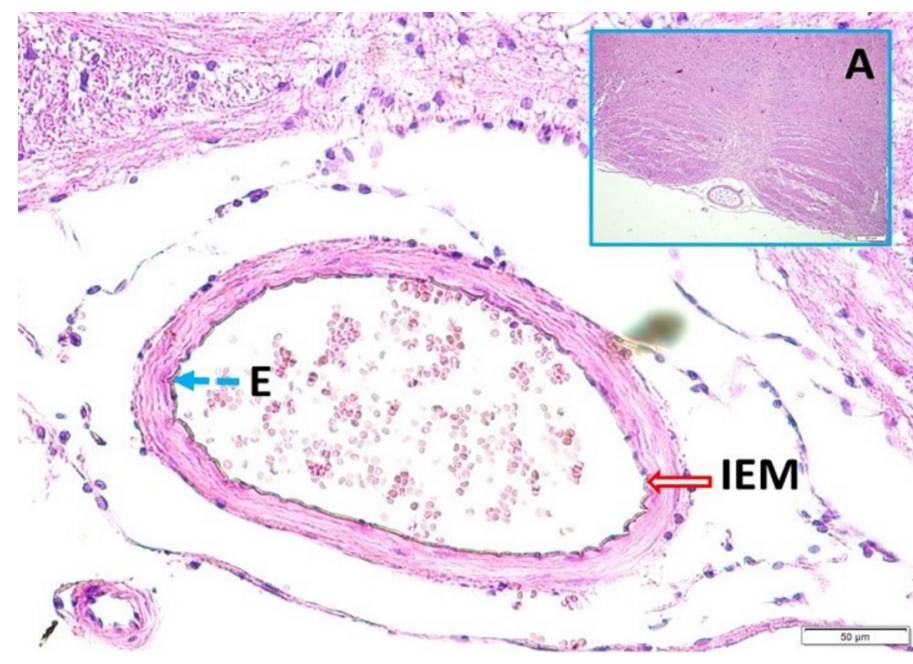

Figure 8. Histopathologic appearance of the basilar artery in the basilar sulcus in the pons (LM, H\&E, 4/A) and magnified form with thickened arachnoid membrane/adventitia, thinned smooth muscles in a thinned wall, significant flattened inner elastic membrane (IEM) endothelium (E) degeneration and endothelial desquamation of male rabbit (LM, H\&E, 20/Base)

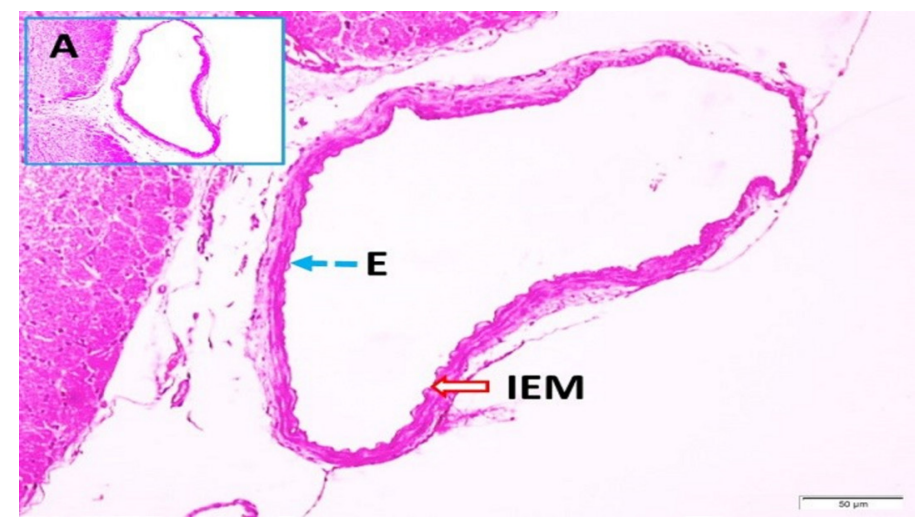

Figure 9. Histopathologic appearance of the basilar artery in the basilar sulcus in the pons (LM, H\&E,4/A) and magnified form with thickened arachnoid membrane/adventitia, thinned smooth muscles in a thinned wall, significant flattened inner elastic membrane (IEM) endothelium (E) degeneration and endothelial desquamation with internal elastic membrane rupture of female rabbit (LM, H\&E, 20/Base).

Basilar arterial volume values were estimated as female rabbits were $3.97 \pm 0.40 \mathrm{~mm} 3$ in control and $6.32 \pm 1.13$ $\mathrm{mm} 3$ in the study group. Basilar arterial volume values were estimated as male rabbits were $3.65 \pm 0.35 \mathrm{~mm} 3$ in control and $4.96 \pm 0.99 \mathrm{~mm} 3$ in the study group. The severity of basilar enlargement was significantly higher in the female rabbits compared with the male rabbits $(p<0.01)$.

\section{DISCUSSION}

High neuron density in stellate ganglia may protect against steno-occlusive carotid artery disease by preventing BA dilatation and aneurysm formation in the posterior circulatory arteries (7). Sympathetic hyperactivity of superior cervical ganglia prevents the severity of dilatation of basilar arteries after bilateral common carotid artery ligation (BCCAL) (8). BCCAL may lead to important beneficial and hazardous histomorphological changes at the posterior communicating artery. The high neuron density of TGG also may provide a beneficial effect by facilitating PComA enlargement via its vasodilatory properties for the increase of decreased cerebral circulation, although this situation may be hazardous for certain subjects with congenital or acquired cerebrovascular pathologies (5). Carotid occlusions are associated with de novo intracranial aneurysm formation with increased tortuosity while presenting segmental dilations of the basilar terminus (9).

Intracranial aneurysm initiation is poorly understood, although hemodynamic insult is believed to play an important role in triggering the pathology. It has recently been found in a rabbit model that while macrophages are absent during hemodynamic aneurysm initiation, matrix metalloproteinases are elevated and co-localize with smooth muscle cells triggered by BCCAL. (10). Hemodynamic insult has been speculated to be a key factor in intracranial aneurysm formation following BCCAL (6). Hemodynamic insult by bilateral common carotid artery ligation has been shown to induce aneurysmal remodeling at the basilar terminus in a rabbit model (11). Increased basilar artery flow results in adaptive basilar artery remodeling until wall shear stress returns to physiological baseline levels. Morphological changes occur rapidly following flow alteration and do not require chronic insult to affect substantial and significant structural transformation (12). Hemodynamic insults at arterial bifurcations are hypothesized to play a key role in intracranial aneurysm formation after common carotid artery ligation (13).

The diameters of the posterior cerebral, posterior communicating, and basilar arteries on the brain surface were larger and more tortuous in BCCAL-treated rats (14). In rat models to induce both focal cerebral ischemia and chronic cerebral hypoperfusion, it is highly desirable to verify the success of vessel occlusion and reopening with the non-invasive method (15). Arteries that belong to the central nervous system have thick and monotonous internal elastic lamina, Willis ring, and no collateral branch to the systemic circulation. Flow increase was induced by the simple ligation of the bilateral common carotid arteries Cineangiography revealed distinct flow increase in the ligation group at 5 weeks after ligation and in the ligation. Histopathologically, severe disruption of the internal elastic lamina and focal thinning of the media were distinct. Endothelial cells were preserved and there was no inflammatory cell infiltration. These morphological features are consistent with increased flow-induced adaptive remodeling. It is suggested that the constancy of the flow may give the arterial tree of the central nervous system these morphological characterizations (16).

Major cerebral collateral arteries enlarge following bilateral ligation of the common and internal carotid arteries. The purpose of this investigation was to determine the relative contribution of cellular hypertrophy 
versus cellular hyperplasia to this vessel change in a morphometric analysis as well as the functional properties of remodeled vessels in an in vitro study. We assessed cell number and vessel dimensions by morphometric analysis of 16 perfusion-fixed rabbit basilar arteries (17). After reducing the number of patent conduit arteries to the brain by bilateral ligation of the carotid artery, the percentage decrease in blood pressure from the aorta to the internal carotid artery distal to the ligation was larger in spontaneously hypertensive rats than in normotensive rats. The pressure drop corresponded to the degree of hypertension as well as to morphometrically determined structural arterial alteration in the main communicating circuit, i.e. larger media to interna smaller internal radius in the posterior communicating arteries, the proximal part of the posterior cerebral arteries, the basilar artery, and the vertebral arteries. The discrepancy between the sum of the luminal cross-sectional areas of the communicating circuit and the luminal areas of the ligated conduit arteries was larger in the hypertensive than in the normotensive rats. It is to be expected that occlusion of conduit arteries to the brain will have a larger impact on the cerebral arterial perfusion pressure head in the presence of such hypertensive structural alterations known to increase flow resistance (18).

An in vitro animal model which examines the effects of sex hormone variations during the menstrual cycle on basilar artery reactivity is presented. Three groups of rabbits were utilized: a chronically depleted control group which received no further hormonal treatment after bilateral surgical oophorectomy (0), simulating menopause, and two groups of intact females, one of which was treated to mimic the estrogen and progesterone surge during the luteal phase $(\mathrm{H})$ and the third group which was acutely estrogen and progesterone depleted after the luteal surges to simulate the immediate premenstrual state $(W)$. We show that both acute and chronic estrogen and progesterone withdrawal significantly increase serotonin sensitivity (ED50) in basilar artery rings. There was no difference between groups for maximum contraction (Tmax) to serotonin, nor optimal resting tension. Furthermore, there was no difference in vasoreactivity and contractility to norepinephrine between groups. To distinguish between the effects of chronic and acute treatment we examined acute estrogen and progesterone superfusion in basilar artery rings from intact non-treated female rabbits. Acute superfusion of pre-contracted and non-pre-contracted artery segments resulted in significant dilatation only when supraphysiologic concentrations of estrogen and progesterone were used. We conclude that both acute and chronic female sex hormone withdrawal selectively increases cerebral vasoreactivity to serotonin (19).

Major cerebral collateral arteries enlarge following bilateral ligation of the common and internal carotid arteries. The purpose of this investigation was to determine the relative contribution of cellular hypertrophy versus cellular hyperplasia to this vessel change in a morphometric analysis as well as the functional properties of remodeled vessels in an in vitro study. We assessed cell number and vessel dimensions by morphometric analysis of 16 perfusion-fixed rabbit basilar arteries. Results demonstrated significant increases in luminal diameter from 761 to 946 micrometers $(p<0.01)$, the medial cross-sectional area from $5.1 \times 104$ to $7.6 \times$ 104 micrometer2 $\left(\mu \mathrm{m}^{2}\right) \quad(\mathrm{p}<0.005)$, smooth muscle cell volume from $9.19 \times 105$ to $1.44 \times 106$ micrometer3 $(\mu \mathrm{m} 3)(\mathrm{p}<0.0005)$, and overall arterial length from 17.41 to $20.36 \mathrm{~mm}(p<0.005)$ in basilar arteries from the eight ligated rabbits compared with the eight sham-operated controls. Smooth muscle cell volume fraction and cell numerical density were unchanged whereas the number of cells per unit length of the artery was increased significantly from 21.5 to 31.0 cells/micrometer $(p<0.05)$. These data indicate that smooth muscle cell hyperplasia rather than hypertrophy contributes to increases in vessel mass. Functional properties of the basilar arteries from 10 ligated and 10 normal control rabbits were analyzed in vitro. Results showed increased contraction to potassium chloride (approximately $74 \%)(p<0.01)$ and increased sensitivity of smooth muscle to acetylcholine $(p<0.05)$ while maximal relaxation was the same as the control in the ligated animals (17).

We have previously shown that the selective estrogen receptor modulator, improves the consequences of ischemic stroke induces endothelium-independent relaxations of cerebral arteries (20). Testosterone has some preventive effects on $\mathrm{SAH}$-induced vasospasm and secondary neuronal injury in rabbits (21). Progesterone holds therapeutic promise in the treatment of cerebral vasospasm following $\mathrm{SAH}(22) \mathrm{K}+$ is a more powerful vasodilator due to a lack of M2 muscarinic ACh receptorinduced inhibition in the female versus male cerebral circulation (23). Arterial bifurcations represent preferred locations for aneurysm formation, especially when they are associated with variations in divider geometry especially in females. This angular widening is associated with basilar bifurcation aneurysms (24). Vertebrobasilar dissection has 3:1 male and 2/3 female predominance (25). NADPH-oxidase activity and function are lower in cerebral arteries of female rats (26).

Financial disclosures: All authors report no financial interests or potential conflicts of interest.

Conflict of Interest: The authors declare that they have no competing interest.

\section{REFERENCES}

1. Oldendorf WH. Trophic changes in the arteries at the base of the rat brain in response to bilateral common carotid ligation. J Neuropathol Exp Neurol. 1989;48(5):534-47.

2. Rots ML, de Borst GJ, van der Toorn A, Moll FL, Pennekamp CWA, Dijkhuizen RM, Bleys R. Effect of bilateral carotid occlusion on cerebral hemodynamics and perivascular innervation: An experimental rat model. J Comp Neurol. 2019;527(14):2263-72. 
3. Kilic M, Kilic B, Aydin MD, Kanat A, Yilmaz I, Eseoglu M, Gundogdu B. Paradoxic Relations between Basilar Artery Reconfiguration and Superior Cervical Ganglia Ischemia After Bilateral Common Carotid Artery Ligation. World Neurosurg. 2019;125:e658e664.

4. Tutino VM, Liaw N, Spernyak JA, Ionita CN, Siddiqui $A H$, Kolega J, Meng H. Assessment of Vascular Geometry for Bilateral Carotid Artery Ligation to Induce Early Basilar Terminus Aneurysmal Remodeling in Rats. Curr Neurovasc Res. 2016;13(1):82-92.

5. Aygul R, Aydin MD, Kotan D, Demir R, Ulvi H, Karalar M, Nalbantoglu NG, Eseoglu M. Role of the trigeminal system on posterior communicating artery remodelization after bilateral common carotid artery ligation. Anal Quant Cytopathol Histpathol. 2013;35(4):217-25.

6. Meng H, Metaxa E, Gao L, Liaw N, Natarajan SK, Swartz DD, Siddiqui AH, Kolega J, Mocco J Progressive aneurysm development following the hemodynamic insult. $J$ Neurosurg. 2011;114(4):1095-103.

7. Yilmaz I, Eseoglu M, Onen MR, Tanrıverdi O, Kilic M, Yilmaz A(1), Musluman AM, Aydin MD, Gündogdu C. Inverse Association Between Basilar Artery Volume and Neuron Density in the Stellate Ganglion Following Bilateral Common Carotid Artery Ligation: An Experimental Study. World Neurosurg. 2017;100:138-43.

8. Eseoglu M, Yilmaz I, Karalar M, Aydin MD, Kayaci S, Gundogdu C, Gunaldi O, Onen MR. The role of sympathectomy on the regulation of basilar artery volume changes in stenoocclusive carotid artery modeling after bilateral common carotid artery ligation: an animal model. Acta Neurochir (Wien). 2014;156(5):963-9.

9. Tutino VM, Mandelbaum M, Choi H, Pope LC, Siddiqui A, Kolega $\mathrm{J}$, Meng $\mathrm{H}$. Aneurysmal remodeling in the circle of Willis after carotid occlusion in an experimental model. J Cereb Blood Flow Metab. 2014;34:415-24.

10. Mandelbaum M, Kolega J, Dolan JM, Siddiqui AH, Meng H.A critical role for proinflammatory behavior of smooth muscle cells in hemodynamic initiation of intracranial aneurysm. PLoS One. 2013;8(9):e74357.

11. Metaxa E, Tremmel M, Natarajan SK, Xiang J, Paluch RA, Mandelbaum M, Siddiqui AH, Kolega J, Mocco J, Meng $\mathrm{H}$. Characterization of critical hemodynamics contributing to aneurysmal remodeling at the basilar terminus in a rabbit model. Stroke. 2010;41(8):1774-82.

12. Hoi $Y$, Gao L, Tremmel $M$, Paluch RA, Siddiqui $A H$, Meng $\mathrm{H}$, Mocco J. In vivo assessment of rapid cerebrovascular morphological adaptation following acute blood flow increase. J Neurosurg. 2008;109(6):1141-7.

13. Gao L, Hoi Y, Swartz DD, Kolega J, Siddiqui A, Meng H. Nascent aneurysm formation at the basilar terminus induced by hemodynamics. Stroke. 2008;39(7):2085-90.

14. Kim SH, Kim EH, Lee BI, Heo JH. Chronic cerebral hypoperfusion protects against acute focal ischemia, improves motor function, and results in vascular remodeling. Curr Neurovasc Res. 2008;5(1):28-36.
15. Yang YM, Feng $X$, Yao ZW, Tang WJ, Liu HQ, Zhang L. Magnetic resonance angiography of carotid and cerebral arterial occlusion in rats using a clinical scanner. J Neurosci Methods. 2008;167(2):176-83.

16. Masuda H, Sugita A, Zhuang YJ. Pathology of the arteries in the central nervous system with special reference to their dilatation: blood flow. Neuropathology. 2000;20(1):98103.

17. Lehman RM, Owens GK, Kassell NF, Hongo K. Mechanism of enlargement of major cerebral collateral arteries in rabbits. Stroke. 1991;22(4):499-504.

18. Fredriksson K, Nordborg C, Johansson BB. The hemodynamic effect of bilateral carotid artery ligation and the morphometry of the main communicating circuit in normotensive and spontaneously hypertensive rats. Acta Physiol Scand. 1984;121(3):241-247.

19. Futo J, Shay J, Block S, Holt J, Beach M, Moss J. Estrogen and progesterone withdrawal increases cerebral vasoreactivity to serotonin in rabbit basilar artery. Life Sci. 1992;50(16):1165-1172.

20. Ramírez-Rosas MB, Cobos-Puc LE, Muñoz-Islas E, González-Hernández A, SánchezLópez A, Villalón CM, Maassenvandenbrink A, Centurión D. Pharmacological evidence that $\mathrm{Ca}^{2}+$ channels and, to a lesser extent, $\mathrm{K}+$ channels mediate the relaxation of testosterone in the canine basilar artery. Steroids. 2011;76(4):409-15.

21. Gürer B, Turkoglu E, Kertmen H, Karavelioglu E, Arikok AT, Sekerci Z. Attenuation of cerebral vasospasm and secondary injury by testosterone following experimental subarachnoid hemorrhage in rabbit. Acta Neurochir (Wien). 2014;156(11):2111-20.

22. Chang CM, Su YF, Chang CZ, Chung CL, Tsai YJ, Loh JK, Lin CL. Pgesterone attenuates experimental subarachnoid hemorrhage-induced vasospasm by upregulation of endothelial nitric oxide synthase via Akt signaling pathway. Biomed Res Int. 2014;2014: 207616.

23. Chrissobolis S, Sobey CG. Influence of gender on K+induced cerebral vasodilatation. Stroke. 2004;35(3):747-52.

24. Tütüncü $F$, Schimansky $S$, Baharoglu $M$, Gao $B$, Calnan $D$, Hippelheuser J, Safain MG, Lauric A, Malek AM. Widening of the basilar bifurcation angle: association with presence of intracranial aneurysm, age, and female sex. J Neurosurg. 2014;121(6):1401-10.

25. Songsaeng D, Srivatanakul K, Krings T, Geibprasert S, Ozanne A, Lasjaunias P. Symptomatic spontaneous vertebrobasilar dissections in children: a review of 29 consecutive cases. J Neurosurg Pediatr. 2010;6(3):233-43.

26. Miller AA, Drummond GR, Mast AE, Schmidt HH, Sobey CG. Effect of gender on NADPH-oxidase activity, expression, and function in the cerebral circulation: role of estrogen. Stroke. 2007;38(7):2142-9. 